\title{
Regional differences in the gender wage gap in Spain ${ }^{1}$
}

\author{
Inés P. Murillo Huertas (ihuertas@unex.es) \\ Raúl Ramos \\ Hipólito Simón
}

\begin{abstract}
This study examines regional differences in the gender wage gap in Spain using matched employer-employee microdata, two different econometric decomposition methods and panel data techniques. Our findings suggest that Spain shows a significant regional heterogeneity in the size of the raw gap, roughly comparable to cross-country differences observed in the European context. The results from the decomposition analysis show that although the bulk of the gender wage gap in Spanish regions is due to differences in the endowments of productive characteristics between males and females there is still a substantial part of the gap that remains unexplained. The analysis of the causes behind the variation of both, the raw and the unexplained gender wage gap by region highlights that several economic, institutional and demographic elements identified in previous studies analysing international differences in the gender wage gap are also relevant to explain regional differences in the gender wage gap in Spain.
\end{abstract}

Keywords: Regional gender wage gaps; decomposition methods; matched employer-employee data; wage setting institutions; industry structure; female working-life decisions.

JEL Codes: J16, J31, J71, R23, E24 


\section{Introduction}

It has been widely demonstrated that women earn lower wages than men even if they hold similar endowments of observed characteristics (see Altonji and Blank, 1999 as an authoritative review of the related literature). Moreover, the fact that equally productive men and women receive different wages has proved to be widespread and persistent, even although in general women's disadvantages in earnings notably diminished since the second half of the preceding century due mainly to the relative improvement in their human capital endowments (Blau and Kahn, 2006). However, being a common result among modern labour markets, gender pay differences remarkably vary by economy. As a matter of example, regarding cross-country differences between OECD members, the gender wage gap, defined as a percentage of the male median wage, widely varies from minimum around $6 \%$ in countries such as Norway, Belgium or Greece to maximum over $20 \%$ in the EEUU, Japan or Korea (OECD, 2015).

Examining these geographical differences has proved to be a question of major interest insofar as it has helped to better understand whether some institutional, economic and demographic factors which are non-susceptible to be controlled for in the earnings equations (e.g. labour market institutions regarding minimum wages or collective bargaining, differences in employment rates by gender or policies aimed at reconciling work and family) underlie the existing gender wage gaps. In particular, cross-country differences in the magnitude of the gender wage gap have been analysed by a number of studies (see Arulampalam, 2007, Blau and Kahn, 1992, 1995, 1996 and 2001, Christophides et al., 2013, Olivetti and Petrongolo, 2008 and 2014 and Polachek and Xiang, 2014 among the most influential ones). Yet, a common limitation emphasized in these studies relates to data constraints as directly comparable information could be difficult to find in databases covering a number of different countries (Salverda and Checchi, 2015). Another common difficulty is to disentangle the part of cross-country differences in the observed gender gap due to institutional and cultural differences and the part due, alternatively, to the contribution of economic and demographic factors. Given these reasons, an interesting approach to the analysis of the geographical variation of the gender wage gap relates to its regional dimension, e.g. how the gender wage gap varies among regions belonging to the same country. Homogeneous databases could then be used to test whether some relevant variables already considered in the comparative international studies can account for variations of the gender wage gap across regions. In addition, unobserved heterogeneity could be better controlled for as regional labour markets share the same institutional and cultural benchmark. However, to the best of our knowledge studies focusing on which factors determine the regional variation of the gender wage gap have to date not been considered and the analysis of the gender gap in wages from a regional point of view has only be 
addressed to evaluate the effects of different policies implemented at a national level (Chu $\mathrm{Ng}$, 2003; Robinson, 2005).

This article examines gender wage gaps at a regional level in Spain and the principal factors driving cross-regional differences in their magnitude using matched employer-employee data. Spain constitutes an interesting case of study as there are big differences in growth and productivity levels but also in the functioning of regional labour markets (De la Fuente, 2002). In particular, richer Spanish regions are situated geographically in the northeast part of the Iberian Peninsula, except Madrid which is located in the centre. These regions are the most industrialized in Spain, although more recently economic growth has been quite intense in the Mediterranean coast thanks to tourism and construction, particularly during the period 2001-2007. These differences explain, at least partially, that regional labour markets also show persistent and large disparities in terms of unemployment rates (Bentolila and Jimeno, 1998; Bande et al., 2008). Moreover, given the specificities of the Spanish collective bargaining system, where wages are mostly established by industry-level agreements operating at an infra-national level, the wage structure substantially differ across Spanish regions (Simón et al., 2006). Consequently, there exists a significant regional heterogeneity in the size of the gap across Spanish regions, which is roughly in the same range than international variations observed in the size of the gap in the European context. To the best of our knowledge regional comparisons of wage differentials for the Spanish economy have only been addressed by a number of authors and from a different perspective that the one we propose here; thus, with regard to these previous studies the present paper provides evidence to further advance in the knowledge of both the factors explaining the existing gender wage gaps at a regional level in Spain and the factors underlying the regional variation in the magnitude of the gap.

From a methodological point of view, both the standard Oaxaca-Blinder and an adaptation of the Juhn et al. $(1991,1993)$ methodology to be used with matched employer-employee data are employed as econometric methods to estimate and decompose the gender wage gaps. In order to analyse which factors are significant in the explanation of the regional variability of the gender wage gap, we then use panel data techniques and regress regional wage gaps on a set of variables referred to regional labour market conditions, productive structure, work-family reconciliation policies and demographic factors, which have been hypothesized to be relevant in the explanation of the geographical differences in the gender wage gap.

As regards the previous literature dealing with the geographical variation of the gender pay gap the added value of our research is twofold. On one hand, by contrast to available data to be used in cross-country comparative studies, we take advantage of a fully comparable dataset referred to different regions belonging to the same country. It allows the disposal of a common 
wage measure (and then a consistent definition of the dependent variable) and a homogeneous sample selection. In addition, this dataset offers representative matched employer-employee microdata for each region containing rich information on both, individual and workplace attributes. This particular characteristic enables to consider more properly supply and, especially, demand factors in the estimation of the earnings equations and, as a consequence, to determine more accurately the relative contribution of both sides of the labour market in shaping the gender pay gap ${ }^{2}$. On the other hand, it could be expected that the influence on unobserved heterogeneity regarding economic, social and/or institutional factors on the estimation of the gender wage gap is better controlled for in the case of different regions belonging to the same country than in the case of different countries.

The rest of the article is organised as follows. Section 2 summarizes the main studies regarding the explanatory factors of the geographical variation of the gender wage gap. Section 3 contains a brief description of the database. Section 4 outlines the econometric techniques applied in the study. The main obtained results are provided and discussed in section 5 and, finally, section 6 concludes.

\section{Literature review}

Gender inequalities in labour market outcomes have been thoroughly studied in the literature, paying especial attention to differences in wages (for a recent review see e.g. Rubery and Grimshaw, 2015). Focusing particularly on gender wage disparities, the seminal contributions of Oaxaca (1973) and Blinder (1973) started a promising field of study regarding which factors are quantitatively important in explaining women disadvantages in earnings with respect to equally productive men. The vast literature on this topic consistently documents that several measured characteristics tend to favour men's wages. Thus, differences by gender in human capital accumulation (and hence productivity); a different degree of assumption of family constraints among men and women, as well as other social and identity norms; the segregation of women into low-paying establishments and in general discriminatory practices in the labour market against women, and, more recently, differences by gender in psychological factors which are relevant to determine labour market outcomes have been recurrently pointed out as core drivers of the enduring gender wage gaps (Altonji and Blank, 1999; Blau and Kahn, 2016; Ponthieux and Meurs, 2015). Nonetheless, even when these explanatory factors are controlled for there is still a nonnegligible part of the gender wage gap that remains unexplained.

\footnotetext{
2 The advantages of using matched employer-employee microdata to study the gender wage gap and its main explanatory factors have been emphasized by Abowd and Kramarz (1999) and Hamermesh (2008), inter alia.
} 
An alternative very valuable approach to further analyse the origin of the gender wage gap relates to its wide variation across countries. A number of studies examining which factors underlie the international heterogeneity in the magnitude of the gender wage gap have showed in a novel way the significant influence of certain institutional, economic and demographic factors in shaping the existing gender wage gaps. Hence, Blau and Kahn (1992, 1995, 1996 and 2001) pioneer works demonstrate that, other things been equal, differences in the wage structure and, by implication, in wage setting institutions among countries greatly explain cross-country differences in the gender wage gap. Thus, higher levels of wage inequality increase the gender wage gap while, by contrast, encompassing collective bargaining agreements that raise minimum wages reduce the gender pay gap since women tend to locate in the lower tail of the wage distribution. More recent studies also conclude that countries with higher union coverage and higher minimum -as compared to median- wages show lower gender wage gaps (Schäfer and Gottschall, 2015). However, the role played by trade union coverage is not unanimous given that McGuinness et al. (2011) document a positive relationship between trade union membership and gender wage gap for the case of Ireland.

Regarding the effects of other remarkable labour market and economic features, Olivetti and Petrongolo (2008) find that international differences in the patterns of sample selection into employment of women are also highly responsible for the international dissimilarities in the gender pay gap. A more positive selection of women into the workforce as compared to men, they argue, implies that a convergence in gender employment rates would imply an increase of the gender wage gap as low-skilled women enter the labour force ${ }^{3}$. This pattern is consistent with the relatively higher (lower) gender wage ratio observed in those countries with lower (higher) employment rates. Moreover, the structure of labour demand derived from each country-specific degree of structural transformation also determines the relative magnitude of its gender gaps (Olivetti and Petrongolo, 2014). Thus, a declining in manufacturing and a subsequent rising in services encourage women to enter the labour force given their relatively favourable endowments to perform these new jobs. ${ }^{4}$ As a consequence, structural transformation can explain a substantial percentage of the international variation in the overall gender bias in labour demand, being the gender gaps in wages and hours worked generally more pronounced for unskilled than for skilled workers, especially in those countries with higher gender employment differentials.

\footnotetext{
3 Also related to women employment prospects, using a harmonized matched employer-employee data for European countries Gannon et al. (2007) and Simón (2012) put particular emphasis on gender differences in the distribution of workers between and within industries -and in particular on female segregation into low-paying workplacesconcluding that these are major factors in the explanation of the gender wage gap within and between countries.

${ }^{4}$ In the same vein Rendall (2013) and Kaya (2014) focus on the skills requirements of jobs typically held by men and women (brawn vs. brain skills) to analyse the gender wage gap from an international perspective.
} 
On the other hand, turning to the possible effects of gender-specific policies on crosscountry variation of the gender pay gap, Arulampalan et al. (2007) document a negative (positive) correlation between family-work reconciliation policies and sticky-floors (glass-ceilings). Thus, it seems that generous family-friend policies contribute to reinforce low-skilled women's ties to firms, preserving then their investment in firm specific human capital and hence their wages. Nevertheless, they also make accessible longer out-of-work times for high-skilled women, then depressing the relative wages for this last group. Along similar lines, Christophides et al. (2013) find that generous family-work policies are associated to higher gender wage gaps at both extremes of the wage distribution, caused by the incorporation of low wage-characteristics women at the bottom and by increasing times out of work at the top.

Finally, Polachek and Xiang (2014) point to country-specific policies and institutions affecting women's long-term career motivation. Focusing on demographical and institutional variables that affect women's lifetime work behaviour, the authors conclude that those countries with fewer encouragements to work for women show higher gender wage gaps. In particular, other things been equal, higher fertility rates lead to higher gender wage gaps. Moreover, the more pronounced the husband-wife age gap at first marriage, the higher the gender wage differential. A direct effect on the gender wage gap is also found for other variables such as the top marginal tax rates or the husband-wife gap in educational attainment. The rationale behind these results relies upon the division of labour in the household. Thus, if women expect to drop out of the labour force along their lifetime more frequently than their male partners then they find weaker incentives to invest in human capital, which, in turn, drive to lower wages.

Although the number of studies analysing the cross-country variation of the gender wage gap is rather scarce, mainly due to data limitations, even less attention has been paid to examine cross-regional differences regarding women lower relative wages. Some works have focused on the regional analysis in order to test the effects of policies implemented at a national level on the gender wage gap. For instance, Chu Ng (2003) studies how the gender pay gap in urban China evolves as economic development spreads out across regions. The author finds that the gender wage gap varies both by region and along the examined period, pointing to an increase of gender discrimination at the later stages of the Chinese economic reform. As a consequence, although the improvement of women productive characteristics during the reforms contributed to decrease their earnings gap with respect to men, the disadvantageous returns to women characteristics counteracted any decline of the gender wage gap. Robinson (2005) assesses the impact of the introduction of a national minimum wage on regional differences in the gender wage gap in Great Britain. Given that the proportion of low-paid workers varied by region and that women tended to be over-represented among them, the introduction of the minimum wage was expected to impact 
the gender wage gap at a different degree by region. The study concludes that the introduction of the minimum wage had a greater impact on the evolution of the gender wage gap of those regions in which women represented a higher proportion among the low-paid workers, although this impact seems to be almost negligible.

Nevertheless, specific analysis of regional gender wage gaps have only focused on gender wage differentials between workers located in urban vs. rural labour markets (see, for instance, Loureiro et al., 2004; Phimister, 2005 and Krug and Nisic, 2011). The main result from this literature is that gender wage gaps are larger in rural areas than in urban ones, a finding that is also confirmed by Hirsch et al (2013) using microdata for Western Germany from 1975 to 2004. These authors also develop a theoretical model explaining this result. In particular, they assume that women are less mobile than men as the former assume more domestic responsibilities. This fact explains that women receive lower wages. However, in more dense populated areas competition between firms is higher than in rural areas; this higher competitive pressure constrains employers' ability to engage in discriminatory practices and, consequently, it reduces the gap compared to rural areas.

To the best of our knowledge regional comparisons of wage differentials for the Spanish case have only be addressed by Alláez and Uribarri (2001), Ramos et al. (2002) and García-Pérez and Jimeno (2007). However, the scope of these papers is far from the purpose of the present one. Thus, Alláez and Uribarri (2001) and Ramos et al. (2002) aim exclusively to estimate regional gender wage gaps on the base of Oaxaca-Blinder decompositions. By contrast, García-Pérez and Jimeno (2007) provide a thorough analysis of whether some regional labour market characteristics impact the regional differences in wage gaps but focus on gaps by sector (public vs. private) and not by gender.

\section{Data}

As mentioned in the Introduction, the present study first explores the heterogeneity in the magnitude and the factors explaining the gender wage gap among the Spanish regions and then analyses how some institutional, economic and demographic variables contribute to the clarification of the origin of these regional gaps.

The first part of the research is based on the microdata of the 2002, 2006 and 2010 waves of the Encuesta de Estructura Salarial (Survey of Earnings Structure; hereafter, EES). The EES is the sample for Spain of the European Structure of Earnings Survey and has been designed as independent cross-sections that are conducted every four years, being currently four available waves (1995, 2002, 2006 and 2010). As the information contained in the EES has increased over time, our research relies on the three last waves, which are indeed those with a greater wealth of information 
and, especially, a more complete coverage of the whole Spanish economy. The design of the survey corresponds to a two-stage sampling of employees working in workplaces registered in the Social Security system, so one of its most important features is the inclusion of matched employeremployee microdata (i.e. observations for various employees in each establishment). ${ }^{5}$ Moreover, the EES is by design representative and contains information disaggregated at the regional level (references are the 17 Spanish comunidades autónomas, or autonomous communities, corresponding to the NUTS 2 units). Thus, it allows carrying out regional analyses using information about the region where the workplace is located.

The method of random selection of units corresponds to a two-stage stratified sampling where the first stage units are workplaces registered in the Spanish Social Security system, while the second stage units are workers. The first stage units are classified according to their economic activity, being each activity stratified by region (17 regions) and size ranges (8 ranges). Stratum sample sizes are obtained by prefixing an admissible error of 5\% in the field of activity and region, being the survey exhaustive for workplaces with more than 499 workers. The units of second stage are then selected among those workers who worked during the whole month of October of the reference year, previously stratified by occupation and, within occupation, by gender (the number of workers selected in each workplace depends on its size and the survey only includes all workers in those workplaces with less than 5 workers). Consequently, the samples of employees per workplace are representative of the population of workers in the workplace, overall and distinguishing by gender. ${ }^{6}$ It is worth mentioning that in this research workplaces with less than two observations have been excluded from the sample in order to allow a proper identification of workplace fixed effects in the econometric estimations.

The dependent variable used in the first part of the research is the gross hourly wage, calculated from the wage corresponding to a representative month (October), divided by the number of hours worked in that month. ${ }^{7}$ The explanatory variables include characteristics of both individuals and their jobs and workplaces. Regarding the former, they are controls related to nationality (natives vs. immigrants, defined according to the nationality); the highest level of education (primary, secondary or tertiary education) and age (less than 30 years, between 30 and 45 years and more than 45 years). The characteristics of the jobs are occupation (nine categories for major occupational groups); years of tenure in the current job and its quadratic form; type of contract (permanent or fixed-term); full time or part time job and the performance of supervisory

\footnotetext{
${ }^{5}$ Unfortunately, EES data correspond to employees and do not include information about the whole labour force so it does not permit to control for potential selection bias into employment with standard econometric techniques.

${ }^{6}$ The average number of observations per workplace in the overall sample is between 12 and 15, according to the year, and the number of females is usually in the range of $30 \%-40 \%$ of the overall sample of employees in each workplace.

${ }^{7}$ October's wage is taken as the reference since being employed in that month is the requisite that defines the survey population. The total number of hours worked in that month is calculated as the worker's normal working week in October multiplied by 4.35 , plus the number of overtime hours worked.
} 
tasks. Finally, workplace attributes are sector (twelve categories); size (six strata) and the type of collective agreement (distinguishing between firm agreement, national sectoral agreement and infra-national sectoral agreement).

In conducting the empirical analysis certain individuals were excluded, namely, those under the age of 16 or over the age of 65 and those with hourly wages of more than two hundred euros. In order to use a homogeneous sectoral coverage for the three last waves, observations corresponding to section O of NACE-2009 (Public administration and defence, compulsory social security) have been removed from the 2010 wave. The final samples are formed by 122,291 employees in 2002, 138,834 in 2006 and 161,412 in 2010. The regional samples are in turn rather ample: they range between 2,206 and 20,027 employees in 2002, between 2,473 and 21,215 in 2006 and between 2,421 and 29,449 in 2010. The descriptive statistics of the samples are shown in Table A.1 in the Appendix.

Once the regional gender wage gaps are estimated using the microdata from the EES, in the second part of the paper several macroeconomic variables measured at a regional level are tested to further analyse the origin of these gender wage gaps. These macroeconomic variables can be classified into three categories: wage structure and labour market institutional variables; other labour market and economic variables, and demographic factors. Beginning with the variables related to the wage structure and wage-setting institutions of the regions, three proxies have been used: a wage inequality index, measured as the 90-10 log differential of the hourly regional wages; the minimum wage, calculated as the minimum national wage relative to average annual regional wages, and finally the union density, calculated as the percentage of trade union membership relative to total workers at a regional level. Regarding other labour market variables, regional employment rates and the weight of the service sector at a regional level have been considered. The first one reflects employment rates at a regional level referred to the $2^{\text {nd }}$ quarter, while the relative weight of the service sector has been estimated as the rate of total employees working in the service sector relative to total employees in each region. Finally, the demographic variables used in this research are population density, the fertility rate and the husband-wife age gap at first marriage. The population density reflects the average population per square kilometre. The fertility rates offer a short-term fertility indicator by region. In particular, it reflects the expected children per woman along her fertile life at a regional level assuming that she maintains the fertility pattern by age observed during the survey year for those women owing to the same cohort. The last demographic indicator has been calculated as the age of husband minus the age of wife at first marriages at a regional level. More details on these can be found in Table A.4 in the Annex. 


\section{Methodology}

Two different approaches have been followed in the empirical analysis. To estimate and decompose regional gender wage gaps we use an extension of the Juhn et al. (1991) decomposition suggested by Blau and Kahn (1992), specifically adapted to be used with matched employeremployee data. To explore the heterogeneity in the magnitude of the estimated regional gender wage gaps we then apply panel data techniques.

Beginning with the explanation of the decomposition method used in the first part of the paper, the technique departs from the estimation of the following semi-logarithmic wage equation:

$$
w_{i j}=X_{i} \beta+\alpha_{j}+\varepsilon_{i j}
$$

wherein $w_{i j}$ is the natural $\log$ of hourly wage of individual $i$ in workplace $j ; X_{i}$ is a vector of controls including individuals' characteristics and those of their jobs and the companies employing them; $\beta$ is a vector of parameters to be estimated (including an intercept); $a_{j}$ is an error component corresponding to workplace $j$ and invariant for all the individuals working in the same workplace and $\varepsilon_{i j}$ is a stochastic error term.

Following the recommendation of Oaxaca and Ransom (1994) and Neumark (1988), the wage structure corresponding to the pool of individuals of both groups (i.e. males and females) is used as the reference wage structure in the decomposition. Identification of the workplace effects is guaranteed, given that there is more than one observation per workplace in the dataset. Since the result of the Hausman's contrast indicates that workplace specific effects are correlated with the rest of the explanatory variables in equation (1), it is estimated by fixed effects (which is equivalent to estimating by ordinary least squares with a set of workplace dummies). Relying on the properties of the ordinary least squares estimator, after the estimation of equation (1) with the pooled data of both groups, the average wage of the subgroup of workers $s$ ( $s=$ males or females) can be expressed as:

$$
\bar{w}^{s}=\bar{X}^{s} \hat{\beta}+\eta \bar{\lambda}^{s}+\sigma \bar{\theta}^{s} \quad \text { where } \bar{\lambda} \sim(0,1), \bar{\theta} \sim(0,1)
$$

where $\bar{w}_{s}$ stands for the mean natural log of the hourly wage of a given group s; $\bar{X}_{s}$ is a vector of the average of the set of explanatory variables for group $\mathrm{s} ; \hat{\beta}_{s}$ is the vector of coefficients estimated with equation (1) and the pooled data of both groups; $\bar{\lambda}_{s}$ is the average standardized workplace effect of group $s ; \eta$ is the standard deviation of workplace effects of the pool of males and females; $\bar{\theta}_{s}$ is the average standardized residual of group s and $\sigma$ is the standard deviation of wage residuals of the pool of workers.

Using the pooled wage structure as the market price references in the decomposition, the wage gap between males and females can be written as follows: 


$$
\bar{w}^{m}-\bar{w}^{f}=\left(\bar{X}^{m}-\bar{X}^{f}\right) \hat{\beta}+\left(\bar{\lambda}^{m}-\bar{\lambda}^{f}\right) \eta+\left(\bar{\theta}^{m}-\bar{\theta}^{f}\right) \sigma=\Delta \bar{X} \hat{\beta}+\Delta \bar{\lambda} \eta+\Delta \bar{\theta} \sigma
$$

where the subscript $m$ is for males and $f$ for females and a $\Delta$ prefix denotes the average difference between males and females in the subsequent variable.

Equation (3) provides a decomposition of the gender wage gap that quantifies the extent to which average wage differences between males and females are related to (a) differences in productive characteristics between males and females, (b) the relative segregation on females into low-wage workplaces and (c) the influence of unobserved elements. More specifically, the first term on the right-hand side of the equation corresponds to the portion of the wage differential attributable to differences in the observed characteristics between the two groups valued at market prices. The second term estimates the influence of workplace-related factors, which is the join result of the relative segregation of each group across workplaces and the dispersion of wage differentials across workplaces. Finally, the third term measures the influence of the unobserved factors in the model (thus comprising the effect of unobserved ability, motivation and discrimination, among others) and is an estimation of intra-workplace gender wage gap for observationally similar individuals.

Note that the sum of the first and second term roughly corresponds to the 'explained' (or characteristics) component of the standard Oaxaca-Blinder decomposition and the third term corresponds with the 'unexplained' (or returns) component of that decomposition. In its simplest form, after the estimation of equation (1) without workplace fixed effects, this technique allows to decompose differences in averages wages between males and females as follows:

$$
\left(\bar{w}^{m}-\bar{w}^{f}\right)=\left(\bar{X}^{m}-\bar{X}^{f}\right) \hat{\beta}^{*}+\left\{\bar{X}^{m}\left(\hat{\beta}^{m}-\hat{\beta}^{*}\right)+\bar{X}^{f}\left(\hat{\beta}^{*}-\hat{\beta}^{f}\right)\right\}
$$

where $\bar{w}^{\prime \prime}$ and $\bar{w}^{f}$ are the average wages of males and females; $\bar{X}^{m}$ and $\bar{X}^{f}$ are the average endowments of characteristics of both groups and $\hat{\beta}^{m}, \hat{\beta}^{f}$ and $\hat{\beta}^{*}$ are the coefficients estimated after the regression of equation (1) for males, females and the pool of both groups, respectively. The first component of the right side of equation (4) represents the effect on the average wage differential caused by differences in characteristics (or 'explained' term), while the second component corresponds to the effect of differences in the coefficients (or 'unexplained' term).

Once the regional gender wage gaps are estimated and decomposed, panel data techniques have been used to correlate the heterogeneity in the magnitude of these gaps with several explanatory variables. To do this, we first order the data into a pooled cross-section structure and, following Polacheck and Xiang (2014), then estimate the next equation:

$$
y_{i t}=X_{i t} \beta+C_{i} \gamma_{i}+v_{i}+\varepsilon_{i t}
$$


where $y_{i t}$ is the estimated gender wage gap (or, alternatively, the unexplained component of the gap) for region $\mathrm{i}$ in year $\mathrm{t} ; X_{i t}$ represents a set of explanatory variables for region $\mathrm{i}$ in year $\mathrm{t} ; v_{i}$ is a region specific error term and $\varepsilon_{i t}$ is a region-time varying error.

Equation (5) is then estimated for both, the raw and the unexplained gender wage gap, applying a fixed effect model by region and by time. By doing so, we can obtain the correlation among the dependent variable (namely, the raw or the unexplained gender wage gap) and the explanatory variables considered in the second part of the research (i.e. wage structure and labour market institutional variables, other labour market and economic variables and demographic factors).

\section{Results}

\subsection{Descriptive evidence}

Table 1 and Figure 1 contain information on the raw gender wage gap in Spanish regions in the years considered (2002, 2006 and 2010), measured in logarithms of hourly wages. As can be observed, the gender wage gap for the overall Spanish economy is quite sizeable, ranging from $0.187 \log$ points in 2002 to $0.201 \log$ points in $2010 .{ }^{8}$ Moreover, there exists a significant regional heterogeneity in the size of the gap. It ranges from a minimum of $0.020 \log$ points (Extremadura in 2002 and 2006) to a maximum of $0.315 \mathrm{log}$ points (Asturias in 2010), with a coefficient of variation (Gini index) between 0.33 and 0.42 (0.17 and 0.23 ), depending on the year (Table 1). On the other hand, although regional gender wage gaps exhibit an important time persistence (the coefficient of correlation between years has values of $0.60,0.72$ and 0.85 and is statistically significant in all cases at the 5\% level at most) certain changes in the size of the gap are also observed in some Spanish regions (Figure 1).

Very interestingly, the magnitude of the heterogeneity of the gender wage gap in Spanish regions is roughly in the same range than international variations observed in the size of the gap (Tables A.2 and A.3 in the Appendix). Actually, according to the same data source than the EES (i.e., the European Structure of Earnings Survey) the unadjusted gender wage gap in EU-27 state members ranged between $4 \%$ and $30 \%$ in 2006 (1\% and $28 \%$ in 2010), with a coefficient of variation of 0.43 (0.42); measured exactly in the same way, it ranged between $2 \%$ and $22 \%$ in 2006 (5\% and $28 \%$ in 2010), with a coefficient of variation of $0.44(0.32)$ for the case of Spanish regions. On the other hand, note that according to this comparative evidence the size of the raw

\footnotetext{
${ }^{8}$ For a thorough analysis of the determinants of the evolution over time of the gender wage gap in Spain in the period under review, see Murillo and Simón (2014).
} 
gender gap for the overall Spanish economy is highly similar to the average of all EU-27 countries, which suggests that Spain could be a highly representative case in the European context.

Table A.1 in the appendix contains the descriptive statistics for the samples used in the analysis. For a matter of space they correspond to the whole sample for the overall Spanish economy, being descriptive statistics of the samples for every Spanish region available from the authors on request. Those statistics reveal significant differences in observed characteristics of male and female employees in Spain. It is noteworthy that whereas differences in the endowments of characteristics tend to be in general detrimental for female wages (i.e. Spanish males have on average higher work experience - proxied by age - and length of tenure and they have also a greater presence in high-skilled occupations, in full-time work and in jobs with supervisory tasks) in certain cases they favour women's wages (Spanish females exhibit higher levels of education and a lower relatively presence of immigrants, and they tend to work also in larger establishments than males do).

\subsection{Econometric decompositions}

Tables 2 and 3 contain the results of the decompositions of the average gender gaps obtained with the standard Oaxaca-Blinder technique using two different specifications of the wage equation (the first one -showed in Table 2- includes only socio-demographic characteristics of individuals such as nationality, age and education, while the second one -showed in Table 3incorporates attributes of the job and the workplace such as tenure, type of contract, full- or parttime, supervisory tasks, occupation, sector, size and type of collective agreement). In turn, Table 4 contains the results of the application of the extension of the Juhn et al. $(1991,1993)$ proposal to decompose average gender wage gaps with a specification of the wage equation that also includes individual and job characteristics but that incorporates workplace fixed effects instead of workplace attributes. For both techniques the first column for each year provides the value of the observed wage gap between males and females and the rest of the column the figures corresponding to the different terms of the decomposition of the right side of equations (4) and (3), respectively. Note that with both techniques the raw gender wage gap is decomposed into two parts (characteristics and returns) and that in every case a positive value for a specific component indicates an unfavourable effect for female wages. For the sake of comparisons, the first row contains the national results and the three last rows provide information on the variation of the results between regions (the rest of the row show the regional results).

Overall, the results of the decompositions of the gaps are rather different depending on the technique and the explanatory factors considered. All in all, they suggest that the Juhn et al. (1991, 1993) decomposition allows to disentangle more properly the origin of the gender wage gap in the 
Spanish labour market and in its regions via taking advantage of the matched employer-employee data of the EES with the introduction of workplace fixed effects. Hence, according to the results of the Oaxaca-Blinder decomposition using just individual characteristics as explanatory variables (Table 2 and Figure 2) differences in the endowments of observed individual characteristics actually tend to favour the wages of Spanish females (who exhibit, for example, better endowments of education: Table A.1). For that reason, the gender wage gap in the whole Spanish labour market and in all the Spanish regions is essentially due to differences in returns and, hence, seems to have an unexplained nature. When attributes of jobs and workplaces are also incorporated as explanatory factors (Table 3 and Figure 2), the results of the decomposition technique suggest that the bulk of the gender wage gap is still mainly due to the unexplained component (for example, according to the national results this component explains between $65 \%$ and $74 \%$ of the raw gap, depending on the year) and that just a minor part is explained, conversely, by differences in the endowment of job and workplace characteristics (with minor exceptions like Extremadura). Yet, according to the results of the Juhn et al. (1991, 1993) decomposition (Table 4 and Figure 2), obtained using a more complete specification of the wage equation with workplace fixed effects, the bulk of the gender gap is due to differences in the endowments of productive characteristics between males and females (the first and second terms of the decomposition jointly justify more than $60 \%$ of the national gap every year, with a slightly higher explanatory power of the effects of the second term, which captures the effect of workplace segregation) although unobservable factors still represent a relevant part of the gap (between 36\% and 39\% of the raw gap at a national level depending on the year). ${ }^{9}$ Note that his last result is observed in all Spanish regions (i.e. the unexplained component is always positive and explains a sizeable part of the raw gap) although the magnitude of the unexplained component exhibits a notable regional variation.

\subsection{Regional gender gaps and regional characteristics}

The results showed in the previous section have allowed us to conclude that individual, job and workplace characteristics are relevant to explain the gender wage gap in Spanish regions. However, as previously mentioned in section 2, cross-country comparative studies have highlighted the role of certain factors that cannot be considered in our previous analysis -such as wage-setting institutions and other economic and demographic factors- but that could influence females decision to both participate in the labour force and with which intensity, and also the relative treatment they receive in the labour market. The scarce literature considering within

\footnotetext{
${ }^{9}$ Note that, by the nature of the decomposition here applied, the value of this last component provides the average intra-workplace wage differential between males and females with the same observed characteristics working in the same workplace. The positive value observed for this component therefore suggests that in general Spanish firms tend to pay lower wages to females than to males with similar observed characteristics, which is consistent with the existence of wide-ranging direct discrimination against females in the Spanish labour market.
} 
country variation of the gender wage gap has also highlighted the role of population density as a determinant of this gap.

In order to check the relevance of these factors in the regional variation of the gender wage gap in Spain, we estimate panel data models using as dependent variables both the observed and the unexplained gender wage gap obtained according to the Juhn et al. (1991, 1993) decomposition for each of the 17 considered Spanish regions in 2002, 2006 and 2010. Regional and time fixed effects are introduced in order to control for potential omitted variable bias. Several explanatory factors are considered in our analysis (see Table A.4). In turn, we consider variables related to the wage structure and labour market institutional variables (i.e. wage inequality, minimum wages and union density), other labour market and economic variables (i.e. employment rates and the weights of the service sector) and, finally, demographic variables (i.e. population density, fertility rates and husband-wife age gaps at first marriage) at a regional level.

The obtained results are shown in Table 5. Although the results provided in this section should be taken with caution due to the reduced number of observations considered in the analysis, they show some noteworthy findings. Thus, the results provided in columns (1) to (5) of Table 5 show that union density, female employment rate, population density and the gap in the age at first marriage seem to exert some influence on regional raw gender wage gaps. In particular, a higher union density and a higher female employment rate imply larger wage gaps, although it is worth mentioning that both variables are only statistically significant at a $10 \%$ significance level. On the other hand, a higher population density reduces the gap, as predicted by Hirsch et al. (2013). Regarding the gap in the age at first marriage, the sign of the coefficient is the opposite of the one expected. One tentative explanation of this anomalous result could be related to the relatively high marriage age in Spain when compared to other developed economies. The decision to marry is mostly taken only once the two members of the couple have achieved some kind of economic stability and, so, in those regions when the age gap is higher, it could be the case that labour market opportunities for female workers are better and, as a result, the wage gap would be lower. In any case, this latest explanation would deserve further investigation.

However, it should be expected that the influence of the above mentioned factors would be more relevant when considering the part of the gender wage gap that remains unexplained once the effect of individual, job and workplaces characteristics has been controlled for. In fact, according to the results from the Juhn et al. $(1991,1993)$ decomposition, regional differences in the unexplained component are still widely marked (see, for example, last column of Table 2 for 2010). Thus, for instance, as can be seen in figure 3, the unexplained component is lower in the southern part of Spain whereas higher values are observed in the northern part of the country, especially in Navarra, Aragon and Catalonia, together with Madrid. Moving to the analysis of the 
factors behind the unexplained component of the gender wage gap -columns (6) to (10) of Table 5- the relative level of the national minimum wage, female employment rate, the gap in the age at first marriage and fertility rates explain part of the regional differences in this component. All coefficients -except the one for population density in column $(6)^{10}$ and, again, the one for the gap in the age at first marriage- have the expected sign reinforcing the idea that not all observed differences in the unexplained component of the gender wage gap can be attributed to a discriminatory component, although the analysis of the remaining differences would deserve further investigation.

\section{Conclusions}

Econometric techniques commonly used to estimate and decompose the gender wage gap for a single economy, although useful, have been proved to face limitations to fully explain the causes of this gap. In this regard, cross-country comparative studies have emerged as a chance of further enquiring into the origin of the gender wage gap by means of considering certain macroeconomic factors that cannot be controlled for in the conventional decomposition techniques. Our research is framed within this context and aims to analyse regional differences in the gender wage gap in Spain first estimating gender wage gaps by region and then correlating the heterogeneity in the obtained results with several variables previously used in cross-country comparative studies. Spain constitutes an interesting case of study as Spanish regional labour markets notably differ regarding its functioning; in addition, the regional perspective entails an advantage with respect to the international one as fully comparable data bases can be used and a more modest variability in the unobserved factors affecting the gender wage gaps can be assumed.

We have used in the empirical analysis matched employer-employee microdata from the 2002, 2006 and 2010 waves of the Encuesta de Estructura Salarial to estimate the raw gender wage gap for the Spanish regions. Next, we have applied different econometric decomposition methods (the standard Oaxaca-Blinder technique and an adaptation of the Juhn, Murphy, Pierce (1991, 1993) methodology to be used with matched employer-employee data) in order to quantify the explained and unexplained components of the gap. Finally, we have used panel data techniques in order to examine the main economic, institutional and demographic factors behind the regional variation in the magnitude of the gender wage gap.

As one of our main findings, we provide evidence on the existence of a sizeable regional heterogeneity in the magnitude of the gap across Spanish regions. Actually, within country variation in the gap is roughly in the same range than international variations observed in the size

\footnotetext{
10 This unexpected sign could be due to the fact that probably the consideration of firm-fixed effects toghether with activity sector dummies in the estimation already captures differences in the degree of competition in local markets.
} 
of the gap in the European context. Regarding its causes, econometric decomposition results suggest that although an important part of the raw gap is related to differences in characteristics (and in particular to the fact that in general males work in better jobs and firms than females), there is still a substantial part of the observed wage differences between males and females that remains unexplained. Moreover, a substantial regional heterogeneity is found in the unexplained component of the gap.

Given the substantial variation by region in both, the raw and the unexplained gender wage gap, our empirical analysis has focused then on the potential determinants of this regional variation using panel data techniques. This exercise has allowed us to conclude that several elements identified in previous international comparisons are also relevant in the explanation of regional differences in the magnitude of the gender wage gap. In particular, we document that the higher the minimum wage and the age gap at the first marriage; the lower the union density, the employment rate and the fertility rate, the lower the gender wage gap. Our analysis also (partially) support the scarce literature focusing on regional differences in the gender wage gap that has identified population density as a potential determinant of the size of this gap.

Our results imply that the regional differences found in the magnitude of the gender wage gap in Spain cannot be fully attributed to differences in the extent of discriminatory practices among the Spanish regions but also to other effects non-susceptible to be controlled for in the econometric decomposition techniques. In particular, wage-setting institutions and certain economic and demographic factors affecting women life-cycle prospects to work are likely to be accountable for a part of the variation of the gender wage gap by region. As a consequence, not only policy measures aiming at closing the observed productive characteristics of men and women, but also other initiatives affecting these demographic and macroeconomic factors can be useful to reduce the existing gender wage gap. 


\section{References}

Abowd, J. and Kramarz, F. (1999): "Econometric analyses of linked employer-employee data", Labour Economics, 6(1), 53-74.

Altonji, J.G. y Blank, R.M. (1999), "Race and gender in the labor market", in O. Ashenfelter and D. Card (eds.), Handbook of Labour Economics, 3, Amsterdam: North-Holland, 3143-3259.

Alláez, R. and Uribarri, M. (2001):"Discriminación salarial por sexo: un análisis del sector privado y sus diferencias regionales en España", ICE: Revista de Economía, 789, 117-138.

Arulampalam, W., Booth, A.L. y Bryan, M.L. (2007), "Is there a glass ceiling over Europe? Exploring the gender pay gap across the wages distribution", Industrial and Labor Relations Review, 60, 163-186.

Bande, R., Fernández, M. and Montuenga, V. (2008): "Regional unemployment is Spain: disparities, bussines cycle and wage setting", Labour Economics, 15(5), 885-914.

Bentolila, S. and Jimeno, J.F. (1998): "Regional unemployment persistence (Spain, 1976-1994)", Labour Economics, 5(1), 25-51.

Blau, F. and Kahn, L.M. (1992): "The gender earnings gap: learning from international comparisons", American Economic Review, 82(2), 533-538.

Blau, F. and Kahn, L.M. (1995): “The gender earnings gap: some international evidence”, in R. Freemand and L. Katz (eds.): Differences and Changes in wage structures, Chicago,IL: University of Chicago Press.

Blau, F. and Kahn, L.M. (1996): "Wage structure and the gender earnings differentials: an international comparison", Economica, 63, S29-S62.

Blau, F. and Kahn, L.M. (2001): "Understanding international differences in the gender pay gap", NBER Working Paper 8200.

Blau, F. and Kahn, L. (2006): The gender pay gap: going, going, going... but not gone, in: Blau, F., Brinton, M. and Grugsky, D. (Eds.), The declining significance of gender? Russell Sage Foundation, New York, pp. 37-66.

Blinder, A. S. (1973), "Wage discrimination: reduced forms and structural estimates", Journal of Human Resources, 8, 436-55.

Christophides, L. N., Polykarpou, A. and Vrachimis, K. (2013): "Gender wage gaps, "sticky floors" and "glass ceilings" in Europe", Labour Economics, 21, pp. 86-102.

Chu Ng, Y. (2007): "Gender earnings differentials and regional economic development in urban China, 1988-97", Review of Income and Wealth, 53(1), 148-166.

De la Fuente, A. (2002): "On the sources of convergence: A close look at the Spanish regions", European Economic Review, 46, 569-599.

Gannon, B., Plasman, R. and Rycx, F. (2007): "Inter-industry wage differentials and the gender wage gap: evidence from European countries", The Economic and Social Review, 38(1), 135-155.

Hamermesh, D. (2008): "Fun with matched firm-employee data: progress and road maps", Labour Economics, 15(4), 662-672.

Hirsch, B., König, M. and Möller, J. (2013): "Is there a gap in the gap? Regional differences in the gender pay gap", Scottish Journal of Political Economy, 60(4), 412-439.

Juhn, C., Murphy, K. and Pierce, B. (1991): "Accounting for the slowdown in black-white convergence", in M. Osters (eds.) Workers and Their Wages, 107-143. Washington DC: American Enterprise Institute Press.

Juhn, C., Murphy, K. and Pierce, B. (1993): "Wage inequality and the rise in returns to skills", Journal of Political Economy, Vol. 101, pp. 410-442.

Kaya, E. (2014): "Gender wage gap trends in Europe: the role of occupational allocation and skill prices", Cardiff Economics Papers n ${ }^{\circ}$ E2014/23.

Krug, G., Nisic, N. (2011): "Is there an urban wage premium for women? A difference-in-difference analysis using propensity score matching", LASER Discussion Paper $n^{\circ} 54$.

López-Bazo, E., Motellón, E. and El-Attar, M. (2011): "Regional heterogeneity in wage distributions: Evidence from Spain", Journal of Regional Science, 51(3), 558-584.

López-Bazo, E. and Motellón, E. (2012): “Human capital and regional wage gaps”, Regional Studies, 46 (10), 1347-1365.

Loureiro, P., Galrao, F. and Sachida, A. (2004): "Race and gender discrimination in the labour market: an urban and rural sector analysis for Brazil", Journal of Economic Studies, 31(2), 129-143. 
McGuinness, S., Kelly, E., O’Connell, P. J. and Callan, T. (2011), The impact of wage bargaining and worker preferences on the gender pay gap, European Journal of Industrial Relations 17(3) 277-293.

Murillo Huertas, I.P. and Simón, H. (2014): "La Gran Recesión y el diferencial salarial por género en España", Hacienda Pública Española/ Review of Public Economics, 208 (1), 39-76.

Oaxaca, R. (1973):"Male-female wage differentials in urban labour markets", International Economic Review, 14, 693-709.

OECD (2015): Gender wage gap (indicator). doi: 10.1787/7cee77aa-en (Accessed on 04 October 2015).

Olivetti, C. and Petrongolo, B. (2008): "Unequal pay or unequal employment? A cross-country analysis of the gender gaps", Journal of Labor Economics, 26, 621-654.

Olivetti, C. and Petrongolo, B. (2014): "Gender gaps across countries: demand, supply and the industry structure”, Review of Economic Dynamics, 17 (4), 842-859.

Phimister, E. (2005): "Urban effects on participation and wages: Are there gender differences?", Journal of Urban Economics, 58, 513-536.

Polachek, S.W. and Xiang, J.J. (2014): The gender pay gap across countries: a human capital approach, forthcoming in: Esther Redmount (ed.), The economics of the family: how the household affects markets and economic growth.

Ponthieux, S. and Meurs, D. (2015): "Gender inequality", in Atkinson A.B. and Bourguignon, F. (Eds.) Handbook of Income Distribution, 2, Elsevier, 981-1146.

Ramos, V, Rey-Maquieira, J. and Tugores, M. (2002): “Análisis empírico de discriminación por razón de género en una economía especializada en turismo", Annals of Tourism Research en Español, 1, 239-258.

Rendall, M. (2013): "Structural change in developing countries: has it decreased gender inequality?", World Development, 45, 1-16.

Robinson, H. (2005): "Regional evidence on the effect of the national minimum wage on the gender pay gap", Regional Studies, 39(7), 855-872.

Rubery, J. and Grimshaw, D. (2015): "The 40-year pursuit of equal pay: a case of constantly moving goalposts", Cambridge Journal of Economics, 39(2), 319-343.

Salverda, W. and Checchi, D. (2015): Labour-market institutions and the dispersion of the wage earnings, in: Atkinson, B. (Eds), Handbook of income distribution, 2, 1535-1727.

Schäfer, A. and Gottschall, K. (2015), "From wage regulation to wage gap: how wage-setting institutions and structures shape the gender wage gap across three industries in 24 European countries and Germany", Cambridge Journal of Economics, 39 (2): 467-496.

Simón, H. (2012): "The gender gap in earnings: and international comparison with European matched employer-employee data", Applied Economics, 44, 1985-1999.

Simón, H., Ramos, R. and Sanromá, E. (2006): "Collective bargaining and regional wage differences in Spain: an empirical analysis", Applied Economics, 38, 1749-1760. 


\section{Tables and Figures}

Table 1. Wage differentials between males and females in Spanish regions.

\begin{tabular}{|c|c|c|c|}
\hline & 2002 & 2006 & 2010 \\
\hline Spain & 0.187 & 0.167 & 0.201 \\
\hline Andalusia & 0.179 & 0.180 & 0.243 \\
\hline Aragon & 0.255 & 0.225 & 0.237 \\
\hline Asturias & 0.183 & 0.219 & 0.315 \\
\hline Balearic Islands & 0.178 & 0.036 & 0.113 \\
\hline Canary Islands & 0.106 & 0.100 & 0.131 \\
\hline Cantabria & 0.123 & 0.188 & 0.191 \\
\hline Castilla y León & 0.168 & 0.106 & 0.163 \\
\hline Castilla-La Mancha & 0.221 & 0.144 & 0.149 \\
\hline Catalonia & 0.276 & 0.254 & 0.229 \\
\hline Comunidad Valenciana & 0.210 & 0.194 & 0.238 \\
\hline Extremadura & 0.024 & 0.021 & 0.048 \\
\hline Galicia & 0.159 & 0.165 & 0.209 \\
\hline Madrid & 0.229 & 0.216 & 0.226 \\
\hline Murcia & 0.120 & 0.106 & 0.136 \\
\hline Navarra & 0.154 & 0.133 & 0.232 \\
\hline Basque Country & 0.162 & 0.158 & 0.239 \\
\hline Rioja & 0.121 & 0.160 & 0.203 \\
\hline Coefficient of variation & 0.359 & 0.418 & 0.328 \\
\hline Gini Index & 0.193 & 0.228 & 0.173 \\
\hline Minimum & 0.024 & 0.021 & 0.048 \\
\hline Maximum & 0.276 & 0.254 & 0.315 \\
\hline
\end{tabular}

Notes: The wage gap corresponds to the differential of the logarithm of the hourly wage. 
Table 2. Decomposition of the differential in average wages

between males and females in Spanish regions. Oaxaca-Blinder decomposition. Model 1.

\begin{tabular}{|c|c|c|c|c|c|c|c|c|c|}
\hline & \multicolumn{3}{|c|}{2002} & \multicolumn{3}{|c|}{2006} & \multicolumn{3}{|c|}{2010} \\
\hline & Raw gap & Character. (1) & Unexpl. (2) & Raw gap & Character. (1) & Unexpl. (2) & Raw gap & Character. (1) & Unexpl. (2) \\
\hline Spain & $0.187 * * *$ & $-0.035^{* * *}$ & $0.221^{* * *}$ & $0.167 * * *$ & $-0.046^{* * *}$ & $0.213^{* * *}$ & $0.201 * * *$ & $-0.027 * * *$ & $0.228^{* * *}$ \\
\hline Andalusia & $0.179 * * *$ & $-0.004 *$ & $0.183^{* * *}$ & $0.180^{* * *}$ & $-0.023 * * *$ & $0.203 * * *$ & $0.243^{* * *}$ & 0.002 & $0.242^{* * *}$ \\
\hline Aragon & $0.255^{* * *}$ & $-0.041 * * *$ & $0.296^{* * *}$ & $0.225^{* * *}$ & $-0.052 * * *$ & $0.276^{* * *}$ & $0.237 * * *$ & $-0.019 * * *$ & $0.256^{* * *}$ \\
\hline Asturias & $0.183^{* * *}$ & $-0.063 * * *$ & $0.246^{* * *}$ & $0.219 * * *$ & $-0.057 * * *$ & $0.276^{* * *}$ & $0.315^{* * *}$ & $-0.016^{* * *}$ & $0.331 * * *$ \\
\hline Balearic Islands & $0.178^{* * *}$ & $-0.025^{* * *}$ & $0.202^{* * *}$ & $0.036 * * *$ & $-0.081 * * *$ & $0.117 * * *$ & $0.113^{* * *}$ & $-0.033^{* * *}$ & $0.146^{* * *}$ \\
\hline Canary Islands & $0.106 * * *$ & $-0.053 * * *$ & $0.159 * * *$ & $0.100 * * *$ & $-0.042 * * *$ & $0.142 * * *$ & $0.131 * * *$ & $-0.022 * * *$ & $0.153^{* * *}$ \\
\hline Cantabria & $0.123^{* * *}$ & $-0.064 * * *$ & $0.186^{* * *}$ & $0.188 * * *$ & $-0.038 * * *$ & $0.227 * * *$ & $0.191 * * *$ & $-0.041 * * *$ & $0.232 * * *$ \\
\hline Castilla y León & $0.168^{* * *}$ & $-0.035^{* * *}$ & $0.203^{* * *}$ & $0.106^{* * *}$ & $-0.078^{* * *}$ & $0.185^{* * *}$ & $0.163^{* * *}$ & $-0.036 * * *$ & $0.198^{* * *}$ \\
\hline Castilla-La Mancha & $0.221 * * *$ & $-0.026 * * *$ & $0.247 * * *$ & $0.144 * * *$ & $-0.073^{* * *}$ & $0.217 * * *$ & $0.149 * * *$ & $-0.067 * * *$ & $0.217 * * *$ \\
\hline Catalonia & $0.276^{* * *}$ & $-0.007 * *$ & $0.283^{* * *}$ & $0.254 * * *$ & $-0.028 * * *$ & $0.282^{* * *}$ & $0.229 * * *$ & $-0.019 * * *$ & $0.248^{* * *}$ \\
\hline Comunidad Valenciana & $0.210^{* * *}$ & $-0.008^{* * *}$ & $0.218^{* * *}$ & $0.194 * * *$ & $-0.021 * * *$ & $0.215^{* * *}$ & $0.238^{* * *}$ & -0.003 & $0.241 * * *$ \\
\hline Extremadura & $0.024 * * *$ & $-0.083 * * *$ & $0.107 * * *$ & $0.021 * * *$ & $-0.102 * * *$ & $0.123^{* * *}$ & $0.048^{* * *}$ & $-0.066 * * *$ & $0.114^{* * *}$ \\
\hline Galicia & $0.159 * * *$ & $-0.051 * * *$ & $0.210^{* * *}$ & $0.165^{* * *}$ & $-0.045^{* * *}$ & $0.210^{* * *}$ & $0.209 * * *$ & $-0.041 * * *$ & $0.249 * * *$ \\
\hline Madrid & $0.229 * * *$ & $-0.022 * * *$ & $0.251 * * *$ & $0.216^{* * *}$ & $-0.022 * * *$ & $0.238^{* * *}$ & $0.226^{* * *}$ & -0.003 & $0.229 * * *$ \\
\hline Murcia & $0.120 * * *$ & $-0.061 * * *$ & $0.181 * * *$ & $0.106^{* * *}$ & $-0.052 * * *$ & $0.158^{* * *}$ & $0.136^{* * *}$ & $-0.035^{* * *}$ & $0.171 * * *$ \\
\hline Navarra & $0.154 * * *$ & $-0.059 * * *$ & $0.213^{* * *}$ & $0.133^{* * *}$ & $-0.059 * * *$ & $0.192 * * *$ & $0.232 * * *$ & $-0.034 * * *$ & $0.266^{* * *}$ \\
\hline Basque Country & $0.162 * * *$ & $-0.053 * * *$ & $0.214 * * *$ & $0.158 * * *$ & $-0.044 * * *$ & $0.202 * * *$ & $0.239 * * *$ & $-0.025^{* * *}$ & $0.263^{* * *}$ \\
\hline Rioja & $0.121 * * *$ & $-0.046 * * *$ & $0.167 * * *$ & $0.160 * * *$ & $-0.055^{* * *}$ & $0.215^{* * *}$ & $0.203^{* * *}$ & $-0.040 * * *$ & $0.243^{* * *}$ \\
\hline Coefficient of variation & 0.361 & -0.556 & 0.221 & 0.420 & -0.442 & 0.242 & 0.328 & -0.666 & 0.237 \\
\hline Minimum & 0.024 & -0.083 & 0.107 & 0.021 & -0.102 & 0.117 & 0.048 & -0.067 & 0.114 \\
\hline Maximum & 0.276 & -0.004 & 0.296 & 0.254 & -0.021 & 0.282 & 0.315 & 0.002 & 0.331 \\
\hline
\end{tabular}

Notes: The table shows the results obtained after applying equation (4) to the different waves of the Encuesta de Estructura Salarial. The specification of the wage equation includes only individual characteristics (nationality, age and education).

${ }^{*} p<0,1 ; * * p<0,05$; *** $p<0,01$ 
Table 3. Decomposition of the differential in average wages

between males and females in Spanish regions. Oaxaca-Blinder decomposition. Model 2.

\begin{tabular}{|c|c|c|c|c|c|c|c|c|c|c|c|c|}
\hline & \multicolumn{4}{|c|}{2002} & \multicolumn{4}{|c|}{2006} & \multicolumn{4}{|c|}{2010} \\
\hline & $\begin{array}{l}\text { Raw } \\
\text { gap }\end{array}$ & $\begin{array}{l}\text { Charac } \\
\text { Indiv. and } \\
\text { job (1) } \\
\end{array}$ & $\begin{array}{l}\text { eristics } \\
\text { Workplace } \\
\text { (2) }\end{array}$ & $\begin{array}{c}\text { Unexpl. } \\
\text { (3) }\end{array}$ & $\begin{array}{l}\text { Raw } \\
\text { gap }\end{array}$ & $\begin{array}{l}\text { Charac } \\
\text { Indiv. and } \\
\text { job (1) } \\
\end{array}$ & $\begin{array}{l}\text { teristics } \\
\text { Workplace } \\
(2) \\
\end{array}$ & $\begin{array}{c}\text { Unexpl. } \\
\text { (3) }\end{array}$ & $\begin{array}{l}\text { Raw } \\
\text { gap }\end{array}$ & $\begin{array}{r}\text { Charac } \\
\text { Indiv. and } \\
\text { job (1) } \\
\end{array}$ & $\begin{array}{l}\text { teristics } \\
\text { Workplace } \\
(2) \\
\end{array}$ & $\begin{array}{c}\text { Unexpl. } \\
\text { (3) }\end{array}$ \\
\hline Spain & $0.187 * * *$ & $0,032 * * *$ & $0,026^{* * *}$ & $0.129 * * *$ & $0.167 * * *$ & $0,031 * * *$ & $0,013^{* * *}$ & $0.123^{* * *}$ & $0.201 * * *$ & $0,060 * * *$ & $0,011 * *$ & $0.130 * * *$ \\
\hline Andalusia & $0.179 * * *$ & $0,035^{* * *}$ & $0,022 * * *$ & $0.122 * * *$ & $0.180 * * *$ & $0,047 * * *$ & $0,029 * * *$ & $0.104^{* * *}$ & $0.243^{* * *}$ & $0,113 * * *$ & $0,027 * * *$ & $0.103^{* * *}$ \\
\hline Aragon & $0.255^{* * *}$ & $0,066^{* * *}$ & $0,046^{* * *}$ & $0.142 * * *$ & $0.225^{* * *}$ & $0,058 * * *$ & $0,025^{* * *}$ & $0.142^{* * *}$ & $0.237 * * *$ & $0,062 * * *$ & $0,016^{* * *}$ & $0.159 * * *$ \\
\hline Asturias & $0.183^{* * *}$ & $0,038 * * *$ & $0,061 * * *$ & $0.084 * * *$ & $0.219 * * *$ & $0,034 * * *$ & $0,073^{* * *}$ & $0.112^{* * *}$ & $0.315^{* * *}$ & $0,118^{* * *}$ & $0,050 * * *$ & $0.147 * * *$ \\
\hline Balearic Islands & $0.178^{* * *}$ & $0,044 * * *$ & $0,039 * * *$ & $0.094 * * *$ & $0.036^{* * *}$ & $-0,032^{* * *}$ & $-0,019 * * *$ & $0.087 * * *$ & $0.113^{* * *}$ & $0,023^{* * *}$ & $-0,011 * *$ & $0.101 * * *$ \\
\hline Canary Islands & $0.106^{* * *}$ & $-0,018^{* * *}$ & $0,017 * * *$ & $0.107 * * *$ & $0.100 * * *$ & 0,005 & 0,002 & $0.093 * * *$ & $0.131 * * *$ & $0,035^{* * *}$ & 0,003 & $0.093 * * *$ \\
\hline Cantabria & $0.123^{* * *}$ & $-0,011 * *$ & $0,053 * * *$ & $0.081 * * *$ & $0.188^{* * *}$ & $0,059 * * *$ & $0,035^{* * *}$ & $0.094 * * *$ & $0.191 * * *$ & $0,042 * * *$ & $0,045^{* * *}$ & $0.104 * * *$ \\
\hline Castilla y León & $0.168^{* * *}$ & $0,035^{* * *}$ & $0,036^{* * *}$ & $0.097 * * *$ & $0.106^{* * *}$ & $-0,001$ & $-0,015 * * *$ & $0.123^{* * *}$ & $0.163^{* * *}$ & $0,036 * * *$ & $-0,019 * * *$ & $0.145^{* * *}$ \\
\hline Castilla-La Mancha & $0.221 * * *$ & $0,050 * * *$ & $0,057 * * *$ & $0.114^{* * *}$ & $0.144 * * *$ & $0,018^{* * *}$ & $0,022 * * *$ & $0.104^{* * *}$ & $0.149 * * *$ & $0,043^{* * *}$ & $-0,014 * * *$ & $0.120 * * *$ \\
\hline Catalonia & $0.276^{* * *}$ & $0,077 * * *$ & $0,037 * * *$ & $0.162 * * *$ & $0.254 * * *$ & $0,057 * * *$ & $0,037 * * *$ & $0.159 * * *$ & $0.229 * * *$ & $0,059 * * *$ & $0,023^{* * *}$ & $0.147 * * *$ \\
\hline Comunidad Valenciana & $0.210 * * *$ & $0,070 * * *$ & 0,007 & $0.133^{* * *}$ & $0.194 * * *$ & $0,056^{* * *}$ & 0,005 & $0.133^{* * *}$ & $0.238^{* * *}$ & $0,106^{* * *}$ & $-0,008$ & $0.140 * * *$ \\
\hline Extremadura & $0.024 * * *$ & $-0,049 * * *$ & $-0,023 * * *$ & $0.096 * * *$ & $0.021 * * *$ & $-0,050 * * *$ & $-0,010^{* *}$ & $0.081 * * *$ & $0.048^{* * *}$ & $-0,012 * * *$ & $-0,021 * * *$ & $0.081 * * *$ \\
\hline Galicia & $0.159 * * *$ & $0,022 * * *$ & $0,013^{* * *}$ & $0.124 * * *$ & $0.165^{* * *}$ & $0,028 * * *$ & $0,012 * * *$ & $0.125^{* * *}$ & $0.209 * * *$ & $0,059 * * *$ & $0,016^{* * *}$ & $0.133^{* * *}$ \\
\hline Madrid & $0.229 * * *$ & $0,070 * * *$ & $0,033^{* * *}$ & $0.126^{* * *}$ & $0.216^{* * *}$ & $0,078 * * *$ & $0,017 * * *$ & $0.121 * * *$ & $0.226 * * *$ & $0,084 * * *$ & $0,017 * * *$ & $0.125^{* * *}$ \\
\hline Murcia & $0.120 * * *$ & $-0,010^{* *}$ & $0,023^{* * *}$ & $0.107 * * *$ & $0.106^{* * *}$ & $-0,032 * * *$ & $0,022 * * *$ & $0.117 * * *$ & $0.136^{* * *}$ & $0,032 * * *$ & $-0,011 * * *$ & $0.114^{* * *}$ \\
\hline Navarra & $0.154 * * *$ & $0,044 * * *$ & 0,007 & $0.103^{* * *}$ & $0.133^{* * *}$ & $0,035 * * *$ & $-0,011 * *$ & $0.110^{* * *}$ & $0.232 * * *$ & $0,018^{* * *}$ & $0,060 * * *$ & $0.154 * * *$ \\
\hline Basque Country & $0.162 * * *$ & $0,032 * * *$ & $0,027 * * *$ & $0.103^{* * *}$ & $0.158^{* * *}$ & $0,034 * * *$ & $0,030 * * *$ & $0.094 * * *$ & $0.239 * * *$ & $0,063^{* * *}$ & $0,041 * * *$ & $0.135^{* * *}$ \\
\hline Rioja & $0.121 * * *$ & $0,025^{* * *}$ & $0,011^{* *}$ & $0.086^{* * *}$ & $0.160^{* * *}$ & $0,025^{* * *}$ & $0,042^{* * *}$ & $0.093^{* * *}$ & $0.203^{* * *}$ & $0,029 * * *$ & $0,059 * * *$ & $0.115^{* * *}$ \\
\hline Coefficient of variation & 0.361 & 1,142 & 0,782 & 0.198 & $* * *$ & 1,471 & 1,372 & 0.188 & 0.328 & 0,661 & 1,725 & 0.185 \\
\hline Minimum & 0.024 & $-0,049$ & $-0,023$ & 0.081 & 0.021 & $-0,050$ & $-0,019$ & 0.081 & 0.048 & $-0,012$ & $-0,021$ & 0.081 \\
\hline Maximum & 0.276 & 0,077 & 0,061 & 0.162 & 0.254 & 0,078 & 0,073 & 0.159 & 0.315 & 0,118 & 0,060 & 0.159 \\
\hline
\end{tabular}

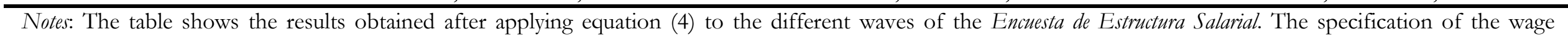
equation includes individual characteristics and attributes of the job and the workplace (nationality, age, education, tenure, type of contract, full- or part-time, supervisory tasks, occupation, region, sector, size and type of collective agreement).

${ }^{*} p<0,1 ;{ }^{* *} p<0,05 ;{ }^{* * *} p<0,01$ 
Table 4. Decomposition of the differential in average wages

between males and females in Spanish regions. Juhn-Murphy-Pierce decomposition.

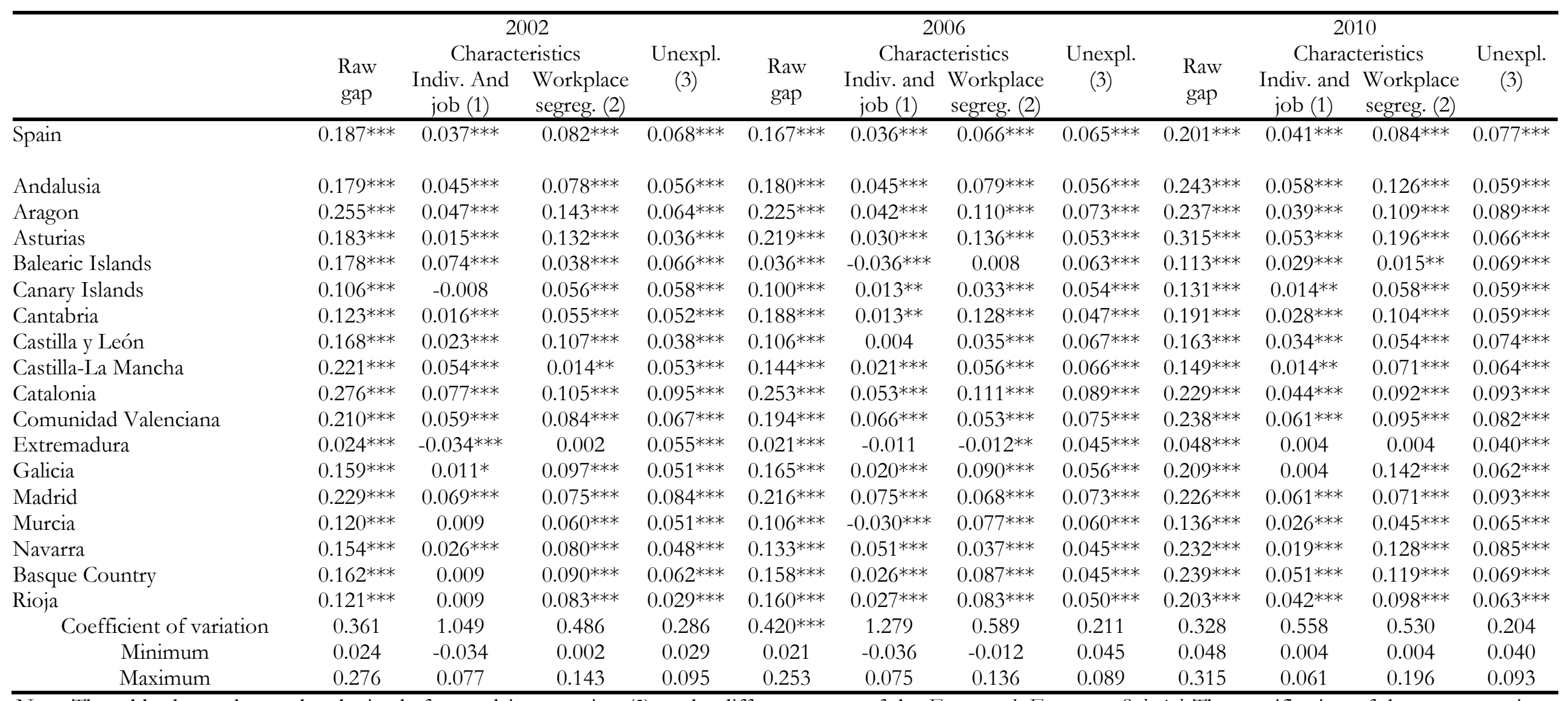

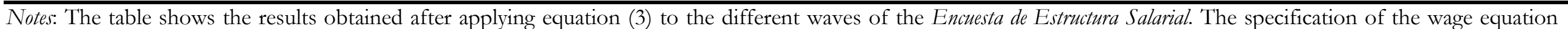

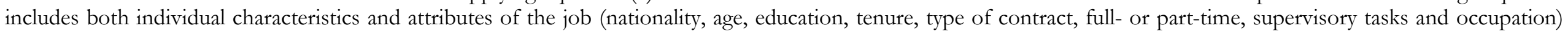
and workplace fixed effects.

${ }^{*} p<0,1$; ** $p<0,05$; *** $p<0,01$ 
Table 5. Determinants of the gender wage gap and the unexplained component of the gender wage gap according to the JMP decomposition.

\begin{tabular}{|c|c|c|c|c|c|c|c|c|c|c|}
\hline & \multicolumn{5}{|c|}{ Raw gender wage gap (1)-(5) } & \multicolumn{5}{|c|}{ Unexplained component of the gap (6)-(10) } \\
\hline & $(1)$ & $(2)$ & $(3)$ & $(4)$ & $(5)$ & $(6)$ & $(7)$ & $(8)$ & $(9)$ & $(10)$ \\
\hline Wage inequality & - & $\begin{array}{l}-0.043 \\
(0.164)\end{array}$ & - & - & - & - & $\begin{array}{l}-0.032 \\
(0.066)\end{array}$ & - & - & - \\
\hline Minimum wage & - & $\begin{array}{l}-0.069 \\
(0.509)\end{array}$ & - & - & - & - & $\begin{array}{c}-0.145^{* *} \\
(0.067)\end{array}$ & - & - & $\begin{array}{c}-0.193^{* *} \\
(0.082)\end{array}$ \\
\hline Union density & - & $\begin{array}{l}0.002^{*} \\
(0.001)\end{array}$ & - & - & - & - & $\begin{array}{c}0.001^{* * *} \\
(0.000)\end{array}$ & - & - & - \\
\hline Female employment rate & - & - & $\begin{array}{l}0.009^{*} \\
(0.004)\end{array}$ & - & $\begin{array}{l}0.009^{*} \\
(0.004)\end{array}$ & - & - & $\begin{array}{l}0.002^{*} \\
(0.001)\end{array}$ & - & $\begin{array}{l}0.002^{* *} \\
(0.001)\end{array}$ \\
\hline Share in services & - & - & $\begin{array}{c}0.002 \\
(0.005)\end{array}$ & - & - & - & - & $\begin{array}{l}-0.001 \\
(0.002)\end{array}$ & - & - \\
\hline Population density (log) & $\begin{array}{c}-0.531^{* * *} \\
(0.190)\end{array}$ & - & - & - & - & $\begin{array}{c}0.078^{* * *} \\
(0.026)\end{array}$ & - & - & - & $\begin{array}{c}0.011 \\
(0.065)\end{array}$ \\
\hline Fertility rate & - & - & - & $\begin{array}{c}0.126 \\
(0.100)\end{array}$ & - & - & - & - & $\begin{array}{c}0.065^{* * *} \\
(0.020)\end{array}$ & - \\
\hline Gap age at first marriage & - & - & - & $\begin{array}{c}-0.057^{* *} \\
(0.025)\end{array}$ & $\begin{array}{c}-0.057^{* *} \\
(0.023)\end{array}$ & - & - & - & $\begin{array}{c}-0.020^{* *} \\
(0.009)\end{array}$ & $\begin{array}{c}-0.022^{* *} \\
(0.008)\end{array}$ \\
\hline Constant & $\begin{array}{c}2.575^{* * * *} \\
(0.861) \\
\end{array}$ & $\begin{array}{r}0.229 \\
(0.354) \\
\end{array}$ & $\begin{array}{l}-0.232 \\
(0.334) \\
\end{array}$ & $\begin{array}{c}0.137 \\
(0.112) \\
\end{array}$ & $\begin{array}{r}-0.015 \\
(0.137) \\
\end{array}$ & $\begin{array}{c}-0.298^{*} \\
(0.118) \\
\end{array}$ & $\begin{array}{c}0.142 \\
(0.095) \\
\end{array}$ & $\begin{array}{c}0.036 \\
(0.122) \\
\end{array}$ & $\begin{array}{c}0.021 \\
(0.023) \\
\end{array}$ & $\begin{array}{l}-0.093 \\
(0.339) \\
\end{array}$ \\
\hline Regional fixed effects (17) & Yes & Yes & Yes & Yes & Yes & Yes & Yes & Yes & Yes & Yes \\
\hline Time fixed effects (3) & Yes & Yes & Yes & Yes & Yes & Yes & Yes & Yes & Yes & Yes \\
\hline Observations & 51 & 51 & 51 & 51 & 51 & 51 & 51 & 51 & 51 & 51 \\
\hline $\mathrm{R}^{2}$ & 0.465 & 0.353 & 0.390 & 0.361 & 0.431 & 0.217 & 0.307 & 0.445 & 0.536 & 0.50 \\
\hline
\end{tabular}

${ }^{*} p<0.10,{ }^{* *} p<0.05,{ }^{* * *} p<0.01$ 
Figure 1. Raw gender wage gap in Spanish regions.

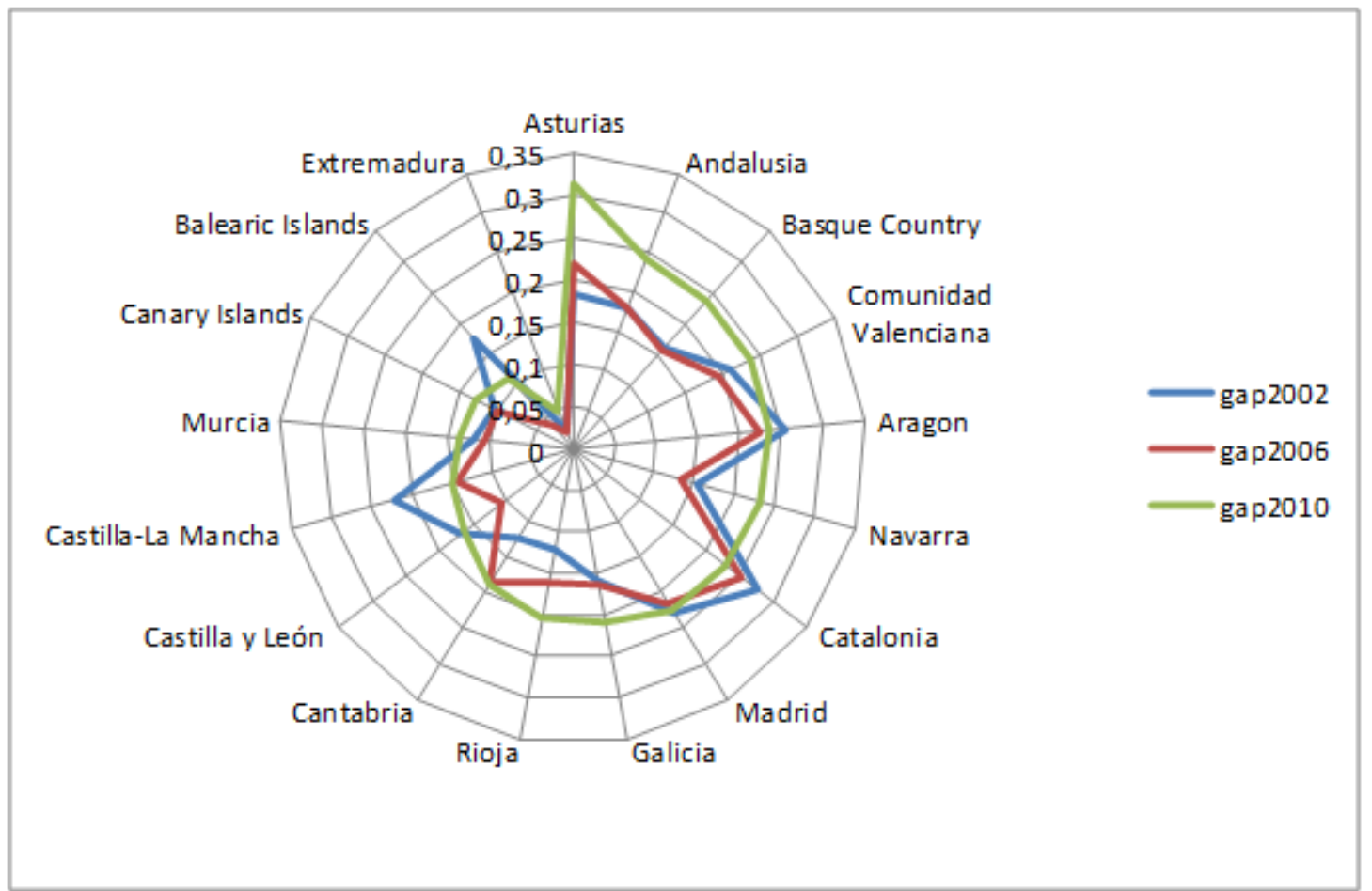


Figure 2. Raw and adjusted gender wage gap in Spanish regions.

Oaxaca-Blinder decomposition (Models 1 and 2) and Juhn-Murphy-Pierce decomposition.

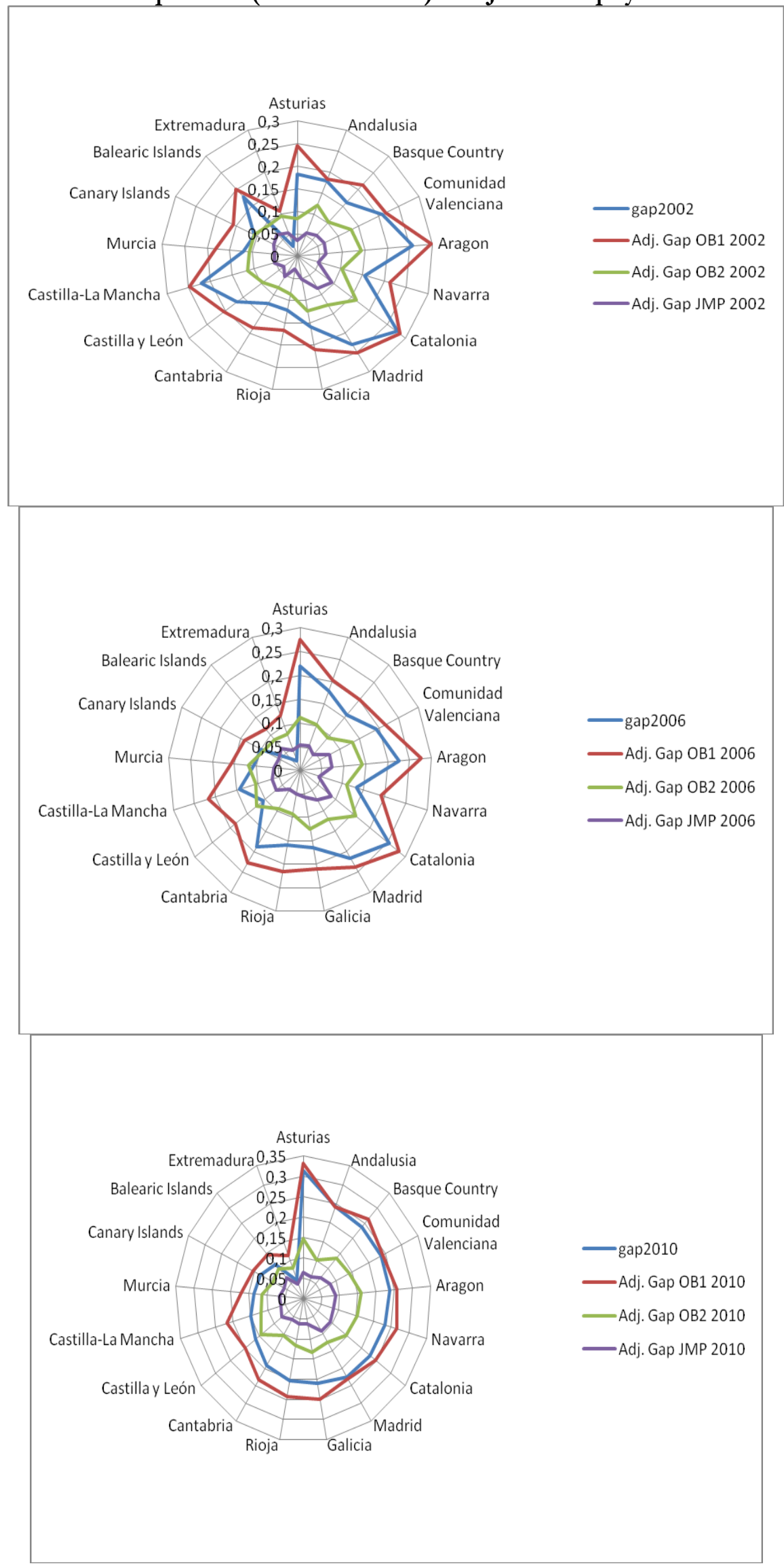


Figure 3. Unexplained component of the gender wage gap in 2010 according to the JMP decomposition.

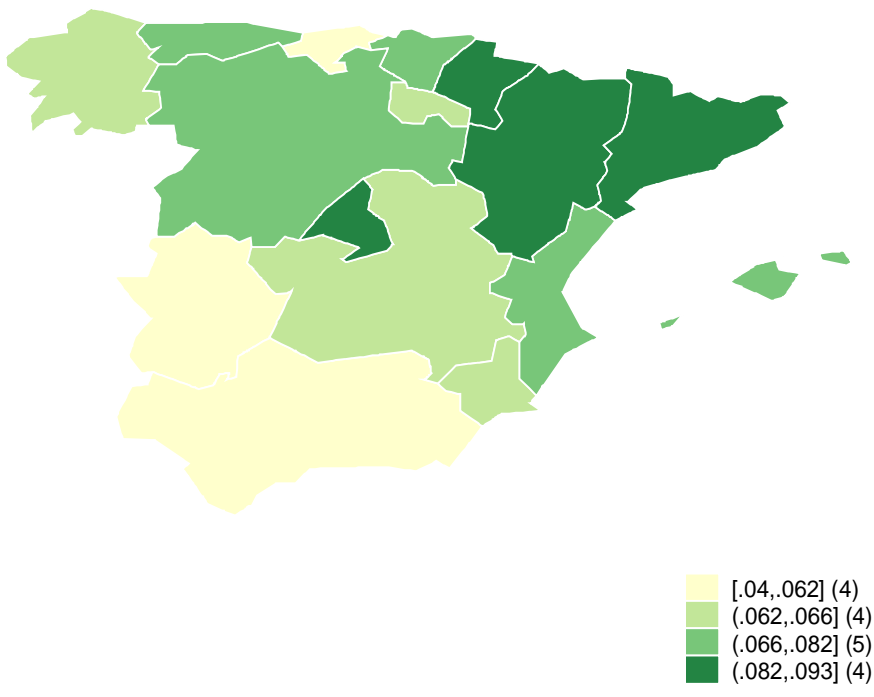




\section{Appendix}

Table A.1. Descriptive statistics (1/2).

\begin{tabular}{|c|c|c|c|c|c|c|}
\hline & \multicolumn{2}{|c|}{2002} & \multicolumn{2}{|c|}{2006} & \multicolumn{2}{|c|}{2010} \\
\hline & Males & Females & Males & Females & Males & Females \\
\hline \multirow{2}{*}{ Hourly wage (euros) } & 9.109 & 7.445 & 10.481 & 8.867 & 13.133 & 10.488 \\
\hline & $(6.32)$ & $(4.56)$ & $(6.87)$ & $(5.58)$ & $(9.73)$ & $(6.61)$ \\
\hline \multirow{2}{*}{ Logarithm of hourly wage } & 2.066 & 1.879 & 2.215 & 2.048 & 2.423 & 2.222 \\
\hline & $(0.49)$ & $(0.47)$ & $(0.48)$ & $(0.49)$ & $(0.51)$ & $(0.47)$ \\
\hline Native & 0.963 & 0.973 & 0.917 & 0.940 & 0.931 & 0.937 \\
\hline Immigrant & 0.037 & 0.027 & 0.083 & 0.060 & 0.069 & 0.063 \\
\hline Age: less than 30 & 0.259 & 0.312 & 0.227 & 0.259 & 0.154 & 0.189 \\
\hline Age: between 30 and 45 & 0.469 & 0.482 & 0.477 & 0.494 & 0.508 & 0.541 \\
\hline Age: more than 45 & 0.272 & 0.205 & 0.296 & 0.247 & 0.338 & 0.270 \\
\hline Primary education & 0.303 & 0.226 & 0.296 & 0.220 & 0.184 & 0.124 \\
\hline Secondary education & 0.548 & 0.525 & 0.527 & 0.494 & 0.591 & 0.567 \\
\hline Tertiary education & 0.149 & 0.249 & 0.177 & 0.286 & 0.224 & 0.309 \\
\hline Tenure & 7.702 & 6.082 & 7.556 & 6.330 & 9.438 & 7.473 \\
\hline Fixed-term contract & 0.733 & 0.722 & 0.713 & 0.710 & 0.785 & 0.773 \\
\hline Part-time job & 0.042 & 0.218 & 0.067 & 0.282 & 0.089 & 0.265 \\
\hline Supervisory tasks & 0.290 & 0.205 & 0.215 & 0.131 & 0.219 & 0.148 \\
\hline Directors and managers & 0.031 & 0.011 & 0.033 & 0.014 & 0.041 & 0.023 \\
\hline Technical and scientific professionals & 0.083 & 0.150 & 0.085 & 0.163 & 0.128 & 0.186 \\
\hline Technicians and associate professionals & 0.133 & 0.144 & 0.126 & 0.143 & 0.192 & 0.171 \\
\hline Office and administrative staff & 0.077 & 0.183 & 0.082 & 0.190 & 0.081 & 0.197 \\
\hline Caterers and vendors & 0.076 & 0.189 & 0.063 & 0.197 & 0.083 & 0.200 \\
\hline Workers skilled in agriculture & 0.002 & 0.000 & 0.003 & 0.000 & 0.004 & 0.001 \\
\hline Skilled workers in manufact. and construction & 0.255 & 0.041 & 0.272 & 0.046 & 0.223 & 0.035 \\
\hline Operators of plant and machinery & 0.238 & 0.092 & 0.206 & 0.059 & 0.154 & 0.052 \\
\hline Elementary occupations & 0.105 & 0.192 & 0.130 & 0.189 & 0.095 & 0.135 \\
\hline Mining and quarrying & 0.017 & 0.002 & 0.013 & 0.002 & 0.006 & 0.001 \\
\hline Manufacturing & 0.436 & 0.260 & 0.389 & 0.196 & 0.376 & 0.192 \\
\hline Production of electricity, gas and water & 0.013 & 0.004 & 0.008 & 0.003 & 0.032 & 0.012 \\
\hline Construction & 0.151 & 0.019 & 0.169 & 0.022 & 0.110 & 0.021 \\
\hline Trade & 0.075 & 0.114 & 0.077 & 0.115 & 0.131 & 0.146 \\
\hline Hospitality & 0.050 & 0.108 & 0.048 & 0.096 & 0.023 & 0.046 \\
\hline Transport and communications & 0.055 & 0.022 & 0.063 & 0.025 & 0.058 & 0.053 \\
\hline Financial intermediation & 0.056 & 0.048 & 0.051 & 0.049 & 0.036 & 0.048 \\
\hline Real estate and rental & 0.068 & 0.156 & 0.089 & 0.186 & 0.139 & 0.237 \\
\hline Education & 0.030 & 0.094 & 0.037 & 0.100 & 0.014 & 0.031 \\
\hline Health & 0.032 & 0.144 & 0.037 & 0.170 & 0.037 & 0.159 \\
\hline Other social and services activities & 0.018 & 0.028 & 0.020 & 0.037 & 0.038 & 0.054 \\
\hline Workplace size less than 20 & 0.218 & 0.183 & 0.233 & 0.186 & 0.226 & 0.210 \\
\hline Workplace size 20-49 & 0.272 & 0.227 & 0.266 & 0.194 & 0.135 & 0.101 \\
\hline Workplace size 50-99 & 0.150 & 0.128 & 0.136 & 0.120 & 0.111 & 0.084 \\
\hline Workplace size 100-199 & 0.111 & 0.109 & 0.106 & 0.102 & 0.142 & 0.113 \\
\hline Workplace size 200-499 & 0.144 & 0.163 & 0.135 & 0.164 & 0.215 & 0.216 \\
\hline Workplace size 500 or more & 0.105 & 0.191 & 0.125 & 0.234 & 0.170 & 0.277 \\
\hline National sectoral collective agreement & 0.356 & 0.414 & 0.376 & 0.424 & 0.284 & 0.332 \\
\hline Sub-national sectoral collective agreement & 0.545 & 0.475 & 0.542 & 0.504 & 0.412 & 0.361 \\
\hline Firm collective agreement & 0.099 & 0.111 & 0.083 & 0.072 & 0.304 & 0.308 \\
\hline
\end{tabular}

Notes: Standard deviation for continuous variables in brackets. 
Table A.1. Descriptive statistics (2/2).

\begin{tabular}{lcccccc}
\hline & \multicolumn{2}{c}{2002} & \multicolumn{2}{c}{2006} & \multicolumn{2}{c}{2010} \\
& Males & Females & Males & Females & Males & Females \\
\hline Number of observations & 78,319 & 43,972 & 82,069 & 56,765 & 94,223 & 67,189 \\
Number of observations by region & & & & & & \\
Andalusia & 7,688 & 4,026 & 8,322 & 4,854 & 9,752 & 6,588 \\
Aragon & 3,855 & 1,808 & 3,811 & 2,364 & 3,742 & 2,380 \\
Asturias & 2,764 & 1,362 & 2,566 & 1,457 & 3,078 & 1,430 \\
Balearic Islands & 2,487 & 1,449 & 2,331 & 1,671 & 2,629 & 1,975 \\
Canary Islands & 3,537 & 1,904 & 3,297 & 2,434 & 3,723 & 2,635 \\
Cantabria & 1,451 & 755 & 1,725 & 1,100 & 2,337 & 1,110 \\
Castilla y León & 3,673 & 1,855 & 4,015 & 2,438 & 3,673 & 2,334 \\
Castilla-La Mancha & 4,271 & 2,062 & 4,689 & 3,309 & 4,829 & 3,190 \\
Catalonia & 11,960 & 8,067 & 11,828 & 9,684 & 15,801 & 13,648 \\
Comunidad Valenciana & 8,760 & 4,315 & 8,754 & 5,081 & 7,995 & 5,439 \\
Extremadura & 1,974 & 1,027 & 2,231 & 1,196 & 2,111 & 1,135 \\
Galicia & 4,978 & 2,713 & 4,799 & 3,283 & 4,968 & 3,508 \\
Madrid & 9,417 & 7,053 & 11,184 & 9,686 & 16,645 & 14,443 \\
Murcia & 3,099 & 1,473 & 3,555 & 2,278 & 2,786 & 1,726 \\
Navarra & 2,096 & 1,110 & 1,994 & 1,423 & 2,773 & 1,446 \\
Basque Country & 4,763 & 2,284 & 5,407 & 3,595 & 5,836 & 3,326 \\
Rioja & 1,546 & 709 & 1,561 & 912 & 1,545 & 876 \\
\hline
\end{tabular}


Table A.2.

Wage differentials between males and females in the European Union.

Gender pay gap in unadjusted form. Structure of Earnings Survey methodology.

\begin{tabular}{|c|c|c|c|}
\hline & 2002 & 2006 & 2010 \\
\hline EU (27 countries) & - & 17.7 & 16.2 \\
\hline Belgium & - & 9.5 & 10.2 \\
\hline Bulgaria & 18.9 & 12.4 & 13.0 \\
\hline Czech Republic & 22.1 & 23.4 & 21.6 \\
\hline Denmark & - & 17.6 & 15.9 \\
\hline Germany & - & 22.7 & 22.3 \\
\hline Estonia & - & 29.8 & 27.7 \\
\hline Ireland & 15.1 & 17.2 & 13.9 \\
\hline Greece & 25.5 & 20.7 & 15.0 \\
\hline Spain & 20.2 & 17.9 & 16.2 \\
\hline France & - & 15.4 & 15.6 \\
\hline Italy & - & 4.4 & 5.3 \\
\hline Cyprus & 22.5 & 21.8 & 16.8 \\
\hline Latvia & - & 15.1 & 15.5 \\
\hline Lithuania & 13.2 & 17.1 & 14.6 \\
\hline Luxembourg & - & 10.7 & 8.7 \\
\hline Hungary & 19.1 & 14.4 & 17.6 \\
\hline Malta & - & 5.2 & 7.2 \\
\hline Netherlands & 18.7 & 23.6 & 17.8 \\
\hline Austria & - & 25.5 & 24.0 \\
\hline Poland & 7.5 & 7.5 & 4.5 \\
\hline Portugal & - & 8.4 & 12.8 \\
\hline Romania & 16.0 & 7.8 & 8.8 \\
\hline Slovenia & 6.1 & 8.0 & 0.9 \\
\hline Slovakia & 27.7 & 25.8 & 19.6 \\
\hline Finland & - & 21.3 & 20.3 \\
\hline Sweden & - & 16.5 & 15.4 \\
\hline United Kingdom & 27.3 & 24.3 & 19.5 \\
\hline Coefficient of variation & 0.355 & 0.428 & 0.419 \\
\hline Minimum & 6.1 & 4.4 & 0.9 \\
\hline Maximum & 27.7 & 29.8 & 27.7 \\
\hline
\end{tabular}

Notes: The unadjusted gender pay gap (GPG) represents the difference between average gross hourly earnings of male paid employees and of female paid employees as a percentage of average gross hourly earnings of male paid employees. The population consists of all paid employees in enterprises with 10 employees or more in NACE Rev. 1.1 aggregate $C$ to $O$ (excluding L) before reference year 2008 and in NACE Rev. 2 aggregate B to S (excluding O) after reference year 2008. The GPG indicator is calculated within the framework of the data collected according to the methodology of the Structure of Earnings Survey.

Source: Eurostat

(http://ec.europa.eu/eurostat/statistics-explained/index.php/Gender pay gap statistics) 
Table A.3.

Wage differentials between males and females in Spanish regions.

Gender pay gap in unadjusted form. Structure of Earnings Survey methodology.

\begin{tabular}{|c|c|c|c|}
\hline & 2002 & 2006 & 2010 \\
\hline Spain & 18.2 & 15.2 & 20.1 \\
\hline Andalusia & 18.2 & 17.2 & 23.8 \\
\hline Aragon & 21.4 & 20.3 & 22.8 \\
\hline Asturias & 15.3 & 15.1 & 28.0 \\
\hline Balearic Islands & 17.9 & 3.5 & 12.9 \\
\hline Canary Islands & 11.2 & 9.5 & 14.1 \\
\hline Cantabria & 8.1 & 15.3 & 18.0 \\
\hline Castilla y Len & 15.5 & 9.0 & 15.2 \\
\hline Castilla-La Mancha & 20.6 & 12.6 & 14.5 \\
\hline Catalonia & 26.2 & 22.5 & 22.8 \\
\hline Comunidad Valenciana & 20.2 & 17.4 & 23.1 \\
\hline Extremadura & 2.2 & 1.7 & 4.7 \\
\hline Galicia & 16.3 & 14.4 & 20.2 \\
\hline Madrid & 23.7 & 21.7 & 24.0 \\
\hline Murcia & 10.5 & 8.3 & 10.1 \\
\hline Navarra & 12.5 & 9.3 & 21.9 \\
\hline Basque Country & 14.6 & 13.0 & 21.7 \\
\hline Rioja & 8.9 & 13.6 & 20.1 \\
\hline Coefficient of variation & 0.397 & 0.444 & 0.320 \\
\hline Minimum & 2.2 & 1.7 & 4.7 \\
\hline Maximum & 26.2 & 22.5 & 28.0 \\
\hline
\end{tabular}

Notes: The unadjusted gender pay gap (GPG) represents the difference between average gross hourly earnings of male paid employees and of female paid employees as a percentage of average gross hourly earnings of male paid employees. The population consists of all paid employees in all enterprises (only enterprises with 10 employees or more in 2002) in NACE Rev. 1.1 aggregate C to $\mathrm{O}$ (excluding L) before reference year 2008 and in NACE Rev. 2 aggregate B to S (excluding O) after reference year 2008.

Source: Own elaboration with EES data. 
Table A.4. Definition of the institutional, economic and demographic explanatory variables of the regional gender wage gaps.

\begin{tabular}{|c|c|c|}
\hline Variable & Source & Definition \\
\hline Wage inequality & $\begin{array}{l}\text { Structure of Earnings Survey } \\
\text { (INE) }\end{array}$ & 90-10 log differential of hourly regional wages \\
\hline Minimum wage & $\begin{array}{l}\text { Boletin Oficial del Estado and } \\
\text { Structure of Earnings Survey } \\
\text { (INE) }\end{array}$ & Minimum relative to average annual regional wages \\
\hline Union density & $\begin{array}{l}\text { Quality of Work Life Survey } \\
\text { (Ministerio de Empleo y Seguridad } \\
\text { Social) }\end{array}$ & Percentage of trade union memberships relative to total workers at a regional level \\
\hline Employment rates & Labour Force Survey (INE) & Employment rates at a regional level refereed to the $2^{\text {nd }}$ quarter \\
\hline Share of services & Spanish Regional Accounts (INE) & $\begin{array}{l}\text { Relative weight of the service sector: total employees working in the service sector relative to total } \\
\text { employees at a regional level }\end{array}$ \\
\hline Population density & $\begin{array}{l}\text { Regional Demographic Statistics } \\
\text { (Eurostat) }\end{array}$ & Average population per square kilometre \\
\hline Fertility rate & $\begin{array}{l}\text { Basic Demographic Indicators } \\
\text { (INE) }\end{array}$ & $\begin{array}{l}\text { Short-term fertility indicator by region: expected children per woman along her fertile life at a regional } \\
\text { level assuming that she maintains the fertility pattern by age observed during the survey year for those } \\
\text { women owing to the same cohort }\end{array}$ \\
\hline $\begin{array}{l}\text { Husband-wife age gap } \\
\text { at first marriage }\end{array}$ & $\begin{array}{c}\text { Basic Demographic Indicators } \\
\text { (INE) }\end{array}$ & Age of husband minus age of wife at first marriages at a regional level \\
\hline
\end{tabular}

